\title{
The Parasitoid Eretmocerus hayati Is Compatible with Barrier Cropping to Decrease Whitefly (Bemisia tabaci MED) Densities on Cotton in China
}

\author{
Xiaoming Zhang ${ }^{1,2}$, Marco Ferrante ${ }^{3,4} \mathbb{D}$, Fanghao Wan ${ }^{1}$, Nianwan Yang $1, * \mathbb{D}$ and
} Gábor L. Lövei 1,5,*(D)

1 State Key Laboratory for Biology of Plant Diseases and Insect Pests, Institute of Plant Protection, Chinese Academy of Agricultural Sciences, Beijing 100193, China; zxmalex@ynau.edu.cn (X.Z.); wanfanghao@caas.cn (F.W.)

2 State Key Laboratory for Conservation and Utilization of Bio-Resources in Yunnan, College of Plant Protection, Yunnan Agricultural University, Kunming 650201, China

3 Mitrani Department of Desert Ecology, Ben Gurion University of the Negev, Sede Boqer Campus, Midreshet Ben Gurion IL-8499000, Israel; marco.ferrante@live.it

4 CE3C-Centre for Ecology, Evolution and Environmental Changes, Azorean Biodiversity Group, Faculty of Agricultural and Environmental Sciences, University of the Azores, PT-9700-042 Angra do Heroísmo, Portugal

5 Department of Agroecology, Aarhus University, Flakkebjerg Research Centre, DK-4200 Slagelse, Denmark

* Correspondence: yangnianwan@caas.cn (N.Y.); gabor.lovei@agro.au.dk (G.L.L.); Tel.: +45-8715-8224 (G.L.L.)

Received: 12 December 2019; Accepted: 15 January 2020; Published: 17 January 2020

Abstract: The whitefly, Bemisia tabaci (Gennadius) cryptic species Mediterranean (MED), is a destructive insect pest worldwide. In order to contribute to controlling B. tabaci by non-chemical methods, we examined the possibility of using a combination of trap/barrier crops and a parasitoid natural enemy in cotton. We performed field experiments using cantaloupe (Cucumis melo) and sunflower (Helianthus annuus) as trap crops and maize (Zea mays) as a barrier crop combined with periodic releases of the parasitoid Eretmocerus hayati in Hebei Province, Northern China. All treatments significantly reduced immature whitefly densities. Parasitism rate was significantly higher in cotton plots intercropped with sunflower and with perimeter-planted cantaloupe. Adult whitefly density was negatively related to parasitoid abundance and was significantly lower in cotton plots intercropped with maize than in the control plots. Intercropping was more effective than perimeter-planting at reducing $B$. tabaci densities and increasing yield. Parasitoid dispersal was not hampered by barrier crops, indicating that the two methods of control are compatible. These results contribute to the development of integrated pest management methods against this important pest.

Keywords: biological control; cantaloupe; sunflower; maize; habitat manipulation; non-chemical pest control

\section{Introduction}

Pest control in modern agriculture has been traditionally reliant on the (initially indiscriminate) use of synthetic pesticides. The emerging problems of pesticide residues, resistance in pests [1], and the damage to natural enemies and various other beneficial arthropods and ecological processes triggered the development of alternative methods of pest control, conceptualized as integrated pest management (IPM) [2]. IPM strategies have been implemented in several countries worldwide and are widely gaining acceptance. For example, IPM is now a mandatory method of plant protection in the European Community [3], but much remains to be further developed and articulated. 
IPM uses various methods, among which intercropping and the use of biological control are prominent elements with lower environmental costs than other alternatives [4,5]. Intercropping is a non-chemical pest control method that relies on modifying pest and natural enemy behavior as well as distribution and density by planting two or more crops on the same field in various spatial arrangements [6-8]. Pests can also be manipulated by attracting or deterring them [9] or by hampering their dispersal by the use of border plants to protect the crop $[10,11]$. These are especially promising when dealing with pests that have a history of fast development of resistance to multiple pesticides.

The whitefly complex Bemisia tabaci (Gennadius) is a "species flock" widely present in tropical and subtropical areas world-wide [12-14]. They cause serious economic damage by direct feeding [15-17] but also as vectors of plant viruses $[13,18]$. The group is very prone to developing resistance to several pesticides $[19,20]$. This makes chemical protection problematic and thus generated interest in various non-chemical methods. Several tall-growing non-host plants, primarily grasses (Gramineae), have been successfully used to reduce whitefly colonization and virus transmission, including sorghum, Sorghum bicolor (L.) Moench [21], pearl millet, Pennisetum typhoides (Burm. f.) Stapf \& Hubbard [22,23], and maize, Zea mays L. [24]. However, the method does not always work; densities of B. tabaci and virus incidence can be higher on cassava when intercropped with maize than in monoculture [25]. Trap and barrier cropping experiments in China indicate that intercropping is more effective than perimeter planting to reduce whitefly densities in cotton, and maize is more effective in this role than sunflower or cantaloupe [26]. Nonetheless, whitefly densities can remain above the economic damage threshold, thus the possibility of combining this with other methods of pest control is worth exploring.

Numerous natural enemies have been introduced to various parts of the world to suppress B. tabaci [27-31]. In several cases, the released natural enemies successfully control the target pest [32,33]. The parasitoid Eretmocerus hayati Zolnerowich and Rose (Hymenoptera: Aphelinidae) is perhaps the most widely used species to manage outbreaks of whiteflies [32]. A host suitability study under laboratory conditions indicates that E. hayati has the highest control potential of $B$. tabaci among currently reported parasitoids in China [34]. As a solitary primary parasitoid, E. hayati shows high preference for $B$. tabaci on various host plants, including tomato, eggplant, poinsettia, and cotton [32,35-37]. Although the release of a parasitoid could suppress whiteflies, this has not always been observed [34,38,39]. In such situations, combination of various methods may offer a solution. However, the successful combined application of natural enemies with intercropping can be constrained by interference between biological control agents and barrier planting methods $[40,41]$. Here, we explored the possibility of combining barrier and trap cropping with periodic release of this parasitoid to examine the compatibility of these two methods of control.

Specifically, we tested the following predictions:

(1) Whitefly densities would remain lower under intercropping than perimeter planting;

(2) The effect of parasitoids would be additive to the effect of barrier cropping;

(3) These treatments would cause an increase in cotton yield.

\section{Materials and Methods}

\subsection{Experimental Design and Plot Management}

The experiments were conducted in 2012 at the Langfang Experimental Station of the Chinese Academy of Agricultural Sciences (CAAS) in Hebei Province (39 30'42" N, 116 36'07" E), Northern China. Plot arrangement was the same as in Zhang et al. (2020). Cotton (cv. Zhongmian 6) was planted on 11 May 2012, while cantaloupe (cv. Elizabeth Hybrid F1), maize (cv. Huaiyan 10), and sunflower (cv. CH 609) were planted on 31 May 2012. Due to a catastrophic rain in the area on 21 July 2012, almost all cantaloupe plants died and had to be replanted using seedlings on 7 August 2012 (Figure 1). 


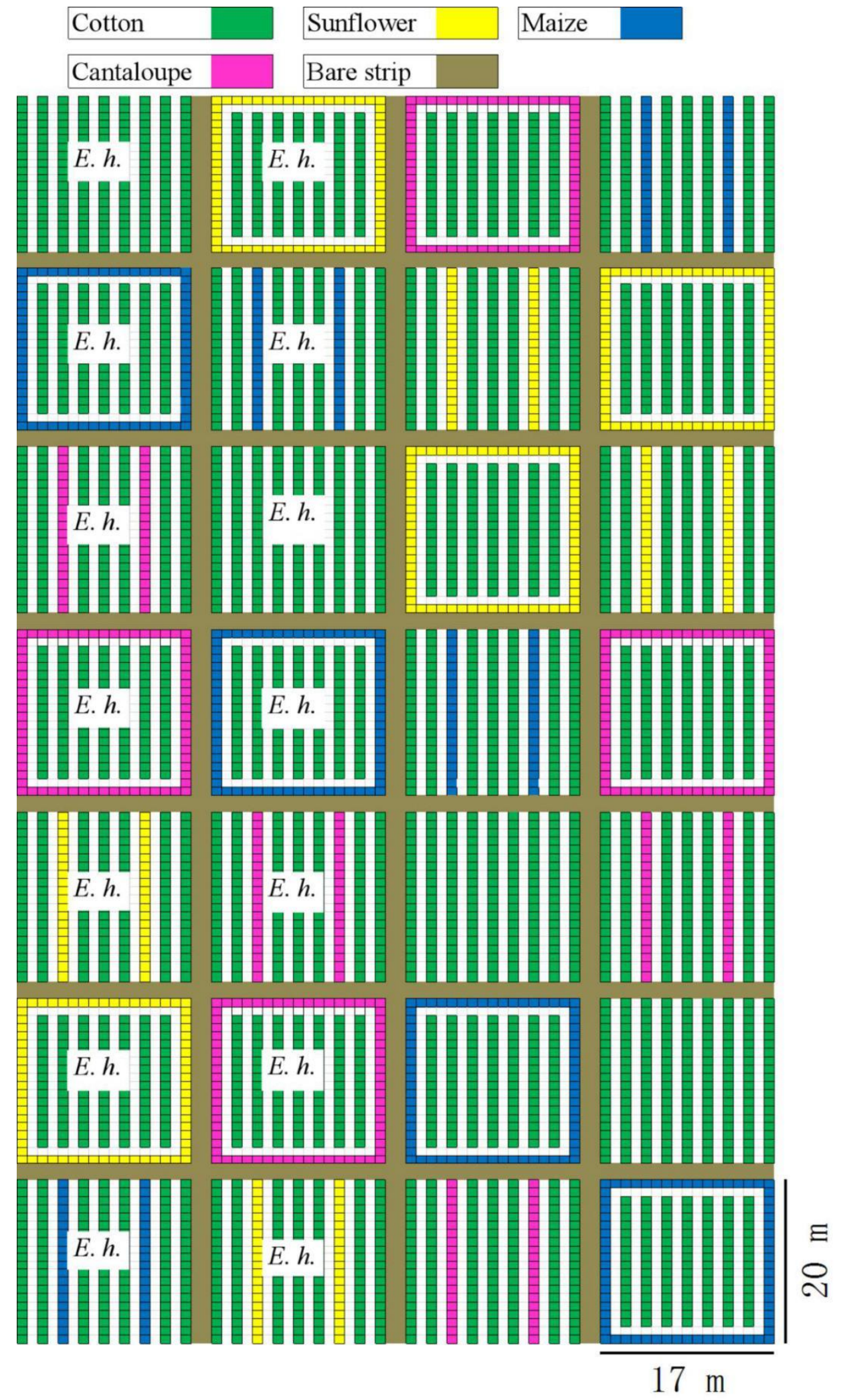

Figure 1. Spatial layout of the field experiment. E. h. indicate that Eretmocerus hayati was released in this plot. Plots $(17 \times 20 \mathrm{~m})$ consisted of nine rows of planting beds, each $20 \mathrm{~m}$ long and $1 \mathrm{~m}$ wide, separated by $1 \mathrm{~m}$ from each other. Each bed was planted with two rows of cotton plants, and each row was planted with 60 plants $33 \mathrm{~cm}$ apart. Plots were separated from each other by a $2 \mathrm{~m}$ wide bare strip. 
Two planting patterns were compared, intercropping and perimeter planting, as detailed in Zhang et al. (2020). The resulting treatments included three intercrop (I) patterns (maize, MI; cantaloupe, $\mathrm{CI}$; and sunflower, SI) and three perimeter (P) plantings (maize, MP; cantaloupe, CP; and sunflower, $\mathrm{SP}$ ). In the control plot, only cotton was planted. Each treatment had four replicates, and the plots were randomly allocated to treatments.

\subsection{Parasitoid Rearing}

We used the aphelinid E. hayati, a solitary parasitoid ovipositing externally under the host nymphs at their 1st-3rd stages [34]. Upon eclosion, the first instar parasitoid larva penetrates the host, feeds, and pupates internally. As the parasitoid larva grows, parasitized nymphs become shiny and yellow, and at a more advanced stage, the eyes of the adult parasitoid wasp are clearly seen through the host skin.

All the host-plants and insects were kept under laboratory conditions at $26 \pm 2{ }^{\circ} \mathrm{C}, 65 \pm 5 \%$ relative humidity $(\mathrm{RH})$, under a 14 h:10 h L:D regime at Langfang Experimental Station. The laboratory colony of $B$. tabaci cryptic species Mediterranean (MED) was collected from greenhouses at the Institute of Vegetables and Flowers, CAAS, Beijing, China and was maintained under glasshouse conditions without exposure to insecticides for 3 years. The species was kept on tomato plants (Solanum lycopersicum cv. He-Zuo 918) obtained from the Shanghai Tomato Research Institute. When tomato seedlings were 10-15 cm tall with 6-8 leaves, they were individually transplanted to flower pots. Then, $6-8$ of these pots were put into a $B$. tabaci rearing cage made of 100 mesh nylon gauze $(1.0 \mathrm{~m}$ long $\times 0.8 \mathrm{~m}$ wide $\times 1 \mathrm{~m}$ tall), and 150 newly emerged adults (sex ratio 1:1) per tomato plant were released into the cage (900-1200 adults) to lay eggs. After $24 \mathrm{~h}$, all the adults were removed. After the emerging B. tabaci reached the 2nd nymphal stage (in 12-14 days), we introduced 5 newly emerged, mated female E. hayati per tomato plant. The development of parasitism in whiteflies was checked every 3 days. When parasitoid pupae appeared, we transferred all parasitoid rearing cages to another room at $16 \pm 1{ }^{\circ} \mathrm{C}$ and $75 \pm 5 \% \mathrm{RH}, 6 \mathrm{~h}: 18 \mathrm{~h} \mathrm{~L}: \mathrm{D}$ regime to delay the development of both host and parasitoid. Cages/pots were kept at this temperature for 15-20 days in preparation for release.

\subsection{Parasitoid Release}

Twenty-four hours before parasitoid release, the potted plants with parasitized whiteflies were transferred to another room with $26 \pm 2{ }^{\circ} \mathrm{C}, 65 \pm 5 \% \mathrm{RH}$, and a $14 \mathrm{~h}: 10 \mathrm{~h}$ L:D regime to prepare the parasitoids for release. At this stage, the numbers were adjusted; a predetermined number of parasitized nymphs were kept on the potted plants, and the rest were removed by hand. After this, the potted plants were placed in the middle of the selected experimental plots. For each treatment, parasitoids were released in two randomly chosen plots, and the other two were kept as release-free controls. The E. hayati release time was chosen to coincide with the peak time of whitefly.

Densities were based on our census in 2011 [26] under calm, sunny periods. Numbers released were determined by the amount of parasitoids available at the time. The first release was on 18 July 2012, when six potted tomato plants were placed in each selected cotton plot with 400 parasitized whitefly nymphs on each (total 2400 E. hayati pupae/plot). On 30 July 2012, three potted tomato plants with 100 parasitized B. tabaci on each were placed out (300 parasitoids/plot), and on 11 August, four potted plants with 150 parasitized B. tabaci (600 parasitoids/plot) were released. This way, a potential total of 3300 parasitoids were released in each plot over 3 weeks. Adult parasitoids started to hatch 5-7 days after the plants were placed outdoors. 


\subsection{Sampling}

\subsubsection{B. tabaci Population}

Field sampling started on 28 June 2012 and was repeated every 10 days until the end of the cotton growing season (8 October 2012). The survey design was identical to Zhang et al. (2020). In each plot, a total of 150 cotton leaves were censused. Adult whiteflies were counted in situ; afterwards, the selected leaves were cut, individually placed in plastic bags, and brought to the laboratory to count nymphs under a dissecting microscope (Olympus, SZ51, 20× magnification). Following this, the area of each leaf was recorded using a transparent mm paper placed over the leaf, from which standardized density data (number of individuals per $100 \mathrm{~cm}^{2}$ leaf surfaces) were calculated [42].

The identity of the whiteflies in the study area was checked as in Zhang et al. (2020), and all individuals tested belonged to B. tabaci MED.

\subsubsection{Parasitoid Census}

Censuses were conducted every 10 days using the same leaves as for the whitefly population census on cotton. Adult parasitoids were counted on the spot. After this, the selected leaves were taken back to the laboratory for examination under a dissecting microscope ( $2 \times$ magnification). Whitefly nymphs with displaced myelomas (symbiotic housing organs) were considered parasitized. The nymphs were subsequently maintained with the host leaf petiole soaking in nutrient solution for an additional 5-7 days in the laboratory until parasitism could be ascertained by the yellow coloration of the E. hayati pupal stage [43]. The first record of parasitoids on cotton leaves was about 3 weeks after the first release, on 8 August (in CP and SI), but densities were very low (0.036 and 0.181 individuals $100 \mathrm{~cm}^{-2}$, respectively). Parasitoids started to be common in all plots from 18 August onwards.

\subsubsection{Cotton Yield}

Cotton yield was determined on a five-point sampling method [44]. On each plot, 2015 plants were randomly selected, and we counted the number of fruiting branches per plant and the number of cotton bolls per branch on 13 October. The mean mass of a cotton boll was measured on 1520 ad hoc selected bolls, and from this, the mass of cotton bolls per plant was estimated. The mature cotton bolls were harvested on three occasions-13 and 22 October and 20 November-then taken back to the laboratory, briefly dried at room temperature for $24 \mathrm{~h}$, and weighed.

\subsection{Data Analysis}

All statistical analyses were performed with the R program, version 3.3 .3 [45], using the packages glmmTMB [46] and lsmeans [47]. The whitefly periods of activity (early, main, and late) were determined following the method by Fazekas et al. (1997) [48], as in Zhang et al. (2020) (Figure 2). In order to unequivocally discern the effectiveness of barrier/trap crops with and without parasitoid release against adult and immature whiteflies, we first analyzed the effects of barrier/trap crops only in plots without parasitoid release (Section 2.5.1) and later in plots with and without parasitoid release (Section 2.5.2). 
(A)

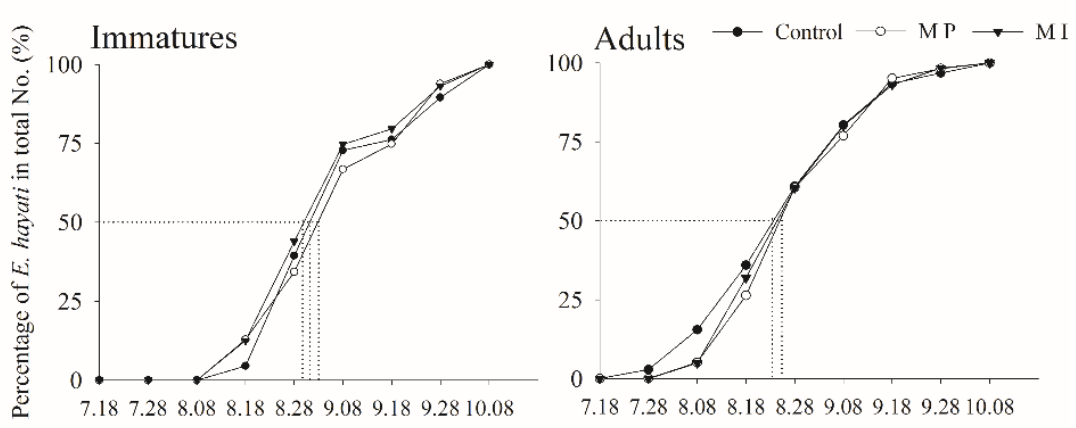

(B)

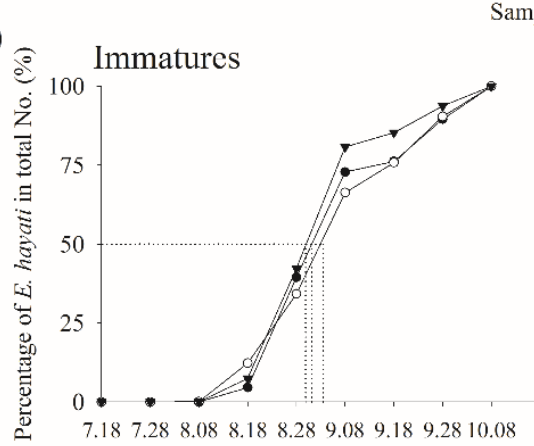

Sampling dates

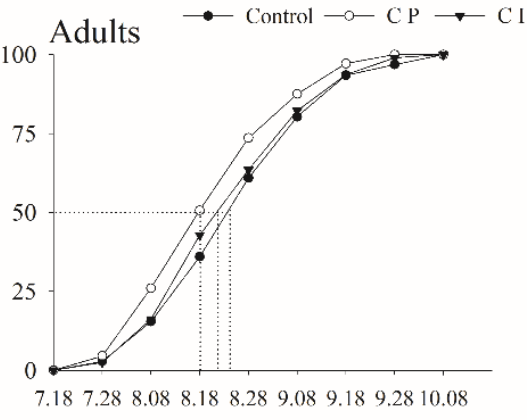

Sampling dates

(C)

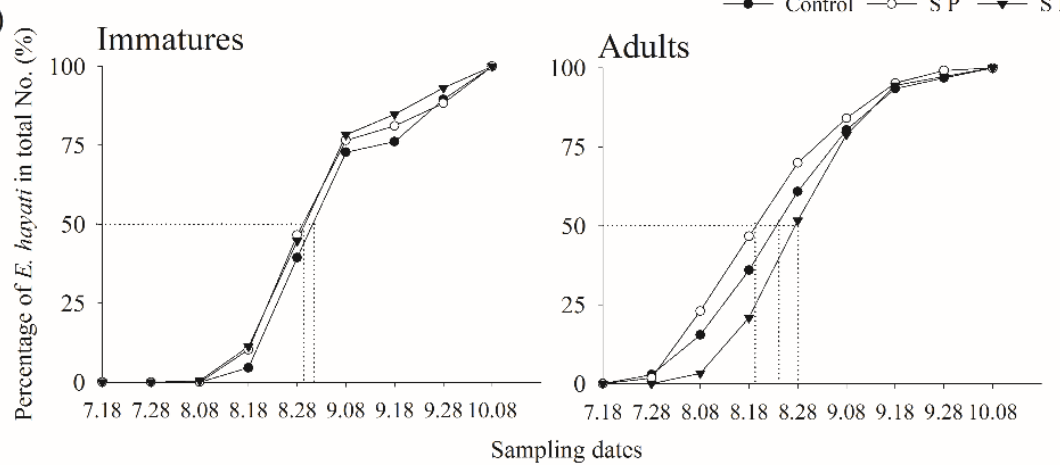

Figure 2. Cumulative seasonal activity curves of Eretmocerus hayati in cotton with inter- or perimeter-cropped maize (A), cantaloupe (B), and sunflower (C) at Langfang, Hebei Province, northern China, in 2012.

\subsubsection{Barrier/Trap Crop Effect}

Average densities of adult and immature whiteflies on cotton leaves were analyzed in two separate generalized linear mixed models (GLMMs) with a Poisson and a negative binomial distribution, respectively. In the initial model, rounded average densities of whiteflies per plot were used as response, treatment was included as fixed factor, and sampling date and activity period were random factors. These models suffered minor underdispersion (dispersion parameter $=0.65$ and 0.86 for adult and immature whitefly densities, respectively). To avoid stronger underdispersion, the final model with adult whitefly densities as response only included treatment and sampling date. Data exploration was carried out according to Zuur et al. (2010) [49] and model validation by investigating Pearson's residuals [50]. LSMeans Tukey's HSD post-hoc test was used to identify significant differences (e.g., [51]).

\subsubsection{Barrier/Trap Crop and Parasitoid Release Effect}

Average densities of adult and immature whiteflies on cotton leaves were analyzed in two separate GLMMs with a Poisson distribution. The initial model was formulated as for the previous analysis, but it also included parasitoid abundance as a fixed factor. Backward model selection was done by 
comparing Akaike Information Criterion (AIC) values [52]. The model with adult whitefly densities as response suffered strong underdispersion (dispersion parameter $=0.30$ ), which was impossible to correct. An additional GLMM with Gaussian distribution, parasitism rate (i.e., the proportion of parasitized immature whitefly per sample) as response, treatment as fixed factor, and sampling date and activity period as random factors was tested. Data exploration, model validation, and post-hoc evaluation were done as for the previous analysis.

\subsubsection{Cotton Yield}

We used ANOVA to test mean yield differences between treatments and the Tukey's post hoc test to reveal significant effects.

\section{Results}

\subsection{Adult and Immature Whitefly and Parasitoid Densities}

The average adult density during the entire season was 1.44 individuals $100 \mathrm{~cm}^{-2}$ leaf surface $(\mathrm{SD}=1.12, n=308)$. Adult densities were 1.15 ind. $100 \mathrm{~cm}^{-2}(\mathrm{SD}=1.05, n=112)$ during the early period, peaked at 2.33 ind. $100 \mathrm{~cm}^{-2}(\mathrm{SD}=1.11, n=84)$ during the main, and were reduced to $1.07 \mathrm{ind}$. $100 \mathrm{~cm}^{-2}(\mathrm{SD}=0.78, n=112)$ during the late season. The average immature density during the entire season was 6.8 individuals $100 \mathrm{~cm}^{-2}(\mathrm{SD}=5.96, n=308)$. Immature densities were 4.21 ind. $100 \mathrm{~cm}^{-2}$ ( $\mathrm{SD}=4.2, n=112)$ during the early season, increasing to 13.33 ind. $100 \mathrm{~cm}^{-2}(\mathrm{SD}=6.19, n=84)$ during the main season before decreasing to 4.50 ind. $100 \mathrm{~cm}^{-2}(\mathrm{SD}=2.73, n=112)$ during the late season. Parasitoid density during the entire season was 0.12 ind. $100 \mathrm{~cm}^{-2}(\mathrm{SD}=0.12, n=224)$, showing a similar seasonal trend: 0.02 ind. $100 \mathrm{~cm}^{-2}(\mathrm{SD}=0.04, n=28)$ during the early, 0.19 ind. $100 \mathrm{~cm}^{-2}$ $(\mathrm{SD}=0.13, n=84)$ during the main, and 0.08 ind. $100 \mathrm{~cm}^{-2}(\mathrm{SD}=0.09, n=112)$ during the late season. Parasitoid seasonality did not differ much between the treatments (Figure 2).

\subsection{Barrier/Trap Crop Effect}

Adult whitefly densities were significantly (LSD Tukey post hoc test, $\mathrm{t}=3.317$, d.f. $=146, p=0.024$ ) lower in plots intercropped with maize (mean $=1.18$ ind. $100 \mathrm{~cm}^{-2}, \mathrm{SD}=0.85, n=22$ ) than in the control (mean $=2.59$ ind. $100 \mathrm{~cm}^{-2}, \mathrm{SD}=1.82, n=22$ ). Other treatments did not have a significant effect on the density of adults, although all of them had densities lower than the control. Maize, either intercropped (mean $=6.09$ ind. $100 \mathrm{~cm}^{-2}, \mathrm{SD}=5.12, n=22$ ) or planted at the perimeter (mean $=5.50$ ind. $100 \mathrm{~cm}^{-2}, \mathrm{SD}=5.44, n=22$ ), and intercropped sunflower (mean $=5.95$ ind. $100 \mathrm{~cm}^{-2}, \mathrm{SD}=4.50, n=22$ ) significantly reduced immature whitefly densities (LSD Tukey post hoc test, $\mathrm{t}=3.189-3.309$, d.f. $=144$, $p=0.0333, p=0.0024$ and $p=0.0236$, respectively) compared to the control (mean $=8.91$ ind. $100 \mathrm{~cm}^{-2}$, $\mathrm{SD}=6.49, n=22)($ Figure $3 \mathrm{~A}, \mathrm{~B})$. 

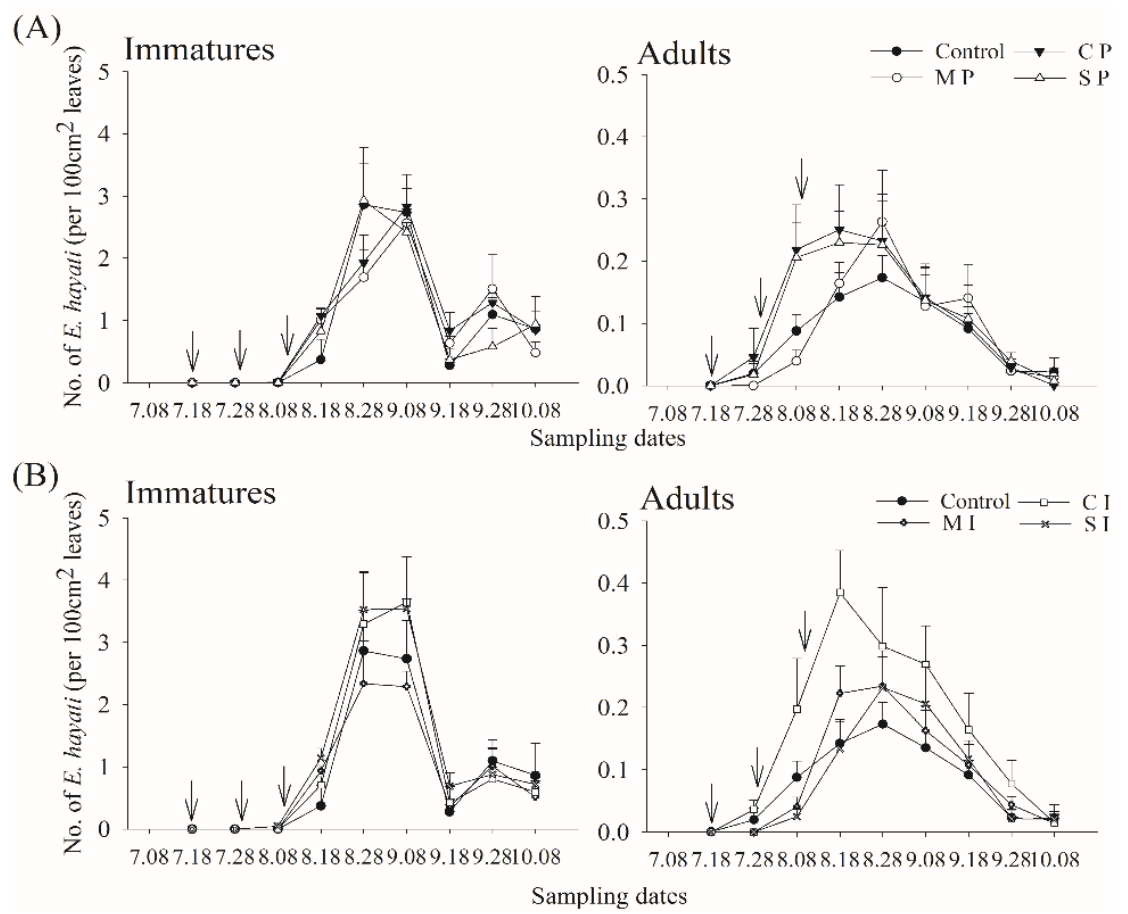

Figure 3. Seasonal dynamics of Eretmocerus hayati (mean $+\mathrm{SE}$ ) on cotton with perimeter- (A) or intercropped (B) maize, cantaloupe, and sunflower at Langfang, Hebei Province, northern China, in 2012. In upper of the figures ' $\downarrow$ ' means $E$. hayati had released in this date in the fields.

\subsection{Barrier/Trap Crop and Parasitoid Release Effect}

Plots intercropped with maize (mean $=1.27$ ind. $100 \mathrm{~cm}^{-2}, \mathrm{SD}=0.70, n=32$ ) or sunflower (mean $=1.36$ ind. $100 \mathrm{~cm}^{-2}, \mathrm{SD}=0.81, n=32$ ) had significantly fewer (LSD Tukey post hoc test, $\mathrm{t}=3.596$ and $\mathrm{t}=3.348$, d.f. $=214, p=0.008$ and $p=0.019$ ) adults than the control (mean $=2.58$ ind. $100 \mathrm{~cm}^{-2}, \mathrm{SD}=1.50, n=32$ ) (Figure 3B). The density of adult whiteflies was negatively affected by parasitoid abundance (GLMM, $\mathrm{z}=-2.479, p=0.013)$. Immature whitefly densities were not affected by parasitoid abundance. However, parasitism rate was significantly higher (LSD Tukey's post-hoc test, $\mathrm{t}=3.263$, d.f. $=157, p=0.028$ and $\mathrm{t}=2.858$, d.f. $=157, p=0.097$, respectively) in plots intercropped with sunflower $($ mean $=22.5, \mathrm{SD}=12.5, n=24)$ and perimeter-planted cantaloupe (mean $=21.3$, $\mathrm{SD}=11.4, n=24)$ than in the control (mean $=13.6, \mathrm{SD}=12.8, n=23$ ) (Figure 3A,B).

\subsection{Yield}

The average cotton yield in the control plots (mean $=109.22 \mathrm{~g} \mathrm{plant}^{-1}, \mathrm{SD}=4.10, n=4$ ) was significantly lower (Tukey's post hoc test, $\mathrm{t}=4.405$ and $\mathrm{t}=3.815$, d.f. $=21, p=0.004$ and $p=0.015$ ) than in plots intercropped with cantaloupe (mean $\left.=134.08 \mathrm{~g} \mathrm{plant}^{-1}, \mathrm{SD}=11.25, n=4\right)$ or maize (mean $\left.=130.75 \mathrm{~g} \mathrm{plant}^{-1}, \mathrm{SD}=8.11, n=4\right)$. The average yield in plots intercropped with cantaloupe was also significantly higher (Tukey's post hoc test, $z=3.382$, d.f. $=21, p=0.038$ ) than in plots with perimeter-planted sunflower $\left(\right.$ mean $\left.=114.99 \mathrm{~g} \mathrm{plant}^{-1}, \mathrm{SD}=6.35, n=4\right)$.

\section{Discussion}

Intercropping was more efficient than perimeter planting in reducing whitefly densities, confirming the findings by Zhang et al. (2020) and our first prediction. In our experiments, parasitoids provided an additional top-down control effect on whitefly densities, indicating that these two methods were compatible in most cases in our study system and supporting our second prediction. In some instances, there were no differences from the control; results varied according to barrier plant or intercropping system, and densities of adults versus immature were occasionally also different. This showed that the 
parasitoids and the whitefly densities were impacted by the planting microenvironment [9] and the general intensity of pesticide use in the landscape [1]. In many cases, intercropping can increase habitat diversity and increase the ability of natural enemies to control target pests. For example, planting buckwheat can enhance parasitism in broccoli [53], and floral understories in a New Zealand apple orchard enhanced parasitism on leafrollers (Lepidoptera: Tortricidae) [54].

However, intercropping does not always work in synergy with natural enemies. In open-field and mesocosm experiments, intercropping collards with parsley limited the effectiveness of natural enemies of aphids [55]. These, however, were non-flying natural enemy species, and their dispersal may have been hampered by the increased habitat complexity [55]. Flying natural enemies may not react to increased above-ground habitat diversity in a similar way. Intercropping squash with buckwheat (Fagopyurm esculentum) in Florida, USA resulted in neither improved yield nor lower pest levels [56]. Canola (Brassica napus L.)-wheat (Triticum aestivum L.) intercrops do not appear to favor parasitism of Delia radicum by either Aleochara bilineata Gyllenhal or A. verna Say (Coleoptera: Staphylinidae) [57]. The dispersal ability of the natural enemy is likely to be an important factor to explain why these two pest control strategies are only sometimes successful together. Eretmocerus hayati disperses mainly at random and with the help of the wind [58]. Maize is a tall plant, and cotton plots with intercropped and perimeter-planted maize may constrain the dispersal ability of this parasitoid. The reduced parasitism rates we found in cotton plots intercropped with sunflower and with perimeter-planted cantaloupe, which are smaller plants, suggest that parasitoid release may be effective in controlling whiteflies densities in these settings.

Cantaloupe, by attracting whiteflies, can reduce whitefly densities in cotton, but its effectiveness is influenced by the planting pattern [26,59]. An interesting difference was the impact of cantaloupe on whitefly densities, which performed well in these experiments but was not similarly effective earlier [26]. The difference was possibly due to the serendipitous weather event, the torrential rain in July 2012 that killed off the earlier-planted cantaloupe. Consequently, these replanted plants were younger than during the previous experiments. This underlines the importance of the timing for such plants; the barrier plants probably act as physical barriers, and thus the taller they are, the more effective they can be. The vegetative state of these plants clearly influences their effect on the target pest, and the attraction may be linked to plant stimuli produced at a younger developmental stage. Further studies could fine-tune the optimal planting time to maximize the intended attractant effect.

Increasing crop diversity can provide more favorable micro-environment, food, alternative host, or prey resources for natural enemies $[60,61]$. In particular, nectar-producing plants can increase the diversity and the fitness of natural enemies, thereby increasing their number and their effect on pest populations $[62,63]$. The attractant approach relies mainly on the plant volatiles, and other plants constitute a physical barrier effect to reduce pest densities, but they could also act through increased farmland biodiversity, ultimately supporting several ecosystem services simply by increasing spatial heterogeneity at the plot/farm scale [64].

The fact that the relative effectiveness of the various barrier and trap crops in reducing whitefly densities were not the same on plots with and without parasitoid release may indicate that parasitoids were not a simple addition to the management system. Possibly, they reacted to the plot environment, including the chemical stimuli from the plants, and modified the final pest densities by their differential reaction. The precise nature of this interaction also needs further study.

From the point of practical benefits, we again proved that using these methods will result in higher per-plant yield, supporting our third prediction.

\section{Conclusions}

Our results indicated that the two non-chemical protection measures, barrier planting and parasitoid release, were compatible in reducing whitefly densities in cotton fields. Parasitism rate is probably influenced by the numbers released in augmentative biological control as well as the level of pesticide use in the landscape, as we found that parasites also invaded plots where they were not 
released. Nonetheless, the employed pest management methods brought clear yield benefits and are promising in the development of non-chemical methods in cotton production.

Author Contributions: Conceptualization and Methodology, X.Z., N.Y., G.L.L., and F.W.; Field Investigation, X.Z.; Data Curation, X.Z., M.F.; Writing-Original Draft Preparation, X.Z., M.F., and G.L.L., Writing-Review and Editing, all authors; Supervision, G.L.L., N.Y., and F.W.; Project Administration, N.Y.; Funding Acquisition, X.Z., N.Y., and F.W. All authors have read and agreed to the published version of the manuscript.

Funding: This research was funded by grants from the National Natural Science Foundation of China (31760541, 31672087), the National Key R \& D Project of China (2016YFC1201200,2017YFC1200600) and the International Science and Technology Cooperation of China (2015DFG32300).

Acknowledgments: The authors thank Haiyun $\mathrm{Xu}$, Meiting Zhao and Qiao Li, Lu Kong, Haiyan Zhao and Xianshuang Wang for help in the field, and the anonymous reviewers for helpful comments.

Conflicts of Interest: The authors declare no conflict of interest. The funders had no role in the design of the study; in the collection, analyses, or interpretation of data; in the writing of the manuscript, or in the decision to publish the results.

\section{References}

1. Whalon, M.E.; Mota-Sanchez, D.; Hollingworth, R.M. Global Pesticide Resistance in Arthropods; CABI: Wallingsford, UK, 2008; ISBN 978-1-84593-379-1.

2. Kogan, M. Integrated pest management: Historical perspectives and contemporary developments. Annu. Rev. Entomol. 1998, 43, 243-270. [CrossRef] [PubMed]

3. Lefebvre, M.; Langrell, S.R.H.; Gomez-y-Paloma, S. Incentives and policies for integrated pest management in Europe: A review. Agron. Sustain. Dev. 2015, 35, 27-45. [CrossRef]

4. Bostanian, N.J.; Goulet, H.; O'Hara, J.; Masner, L.; Racette, G. Towards insecticide free apple orchards: Flowering plants to attract beneficial arthropods. Biocontrol Sci. Technol. 2004, 14, 25-37. [CrossRef]

5. Begg, G.S.; Cook, S.M.; Dye, R.; Ferrante, M.; Franck, P.; Lavigne, C.; Lövei, G.L.; Mansion-Vaquie, A.; Pell, J.K.; Petit, S.; et al. A functional overview of conservation biological control. Crop Prot. 2017, 97, 145-158. [CrossRef]

6. Andow, D. Effect of agricultural diversity on insect populations. In Proceedings of the 4th IFOAM International Scientific Conference, Malaysia, 29-31 August 1983; Praeger Science: New York, NY, USA, 1983; pp. 91-116.

7. Andrews, D.J.; Kassam, A.H. The importance of multiple cropping in increasing world food supplies. In Multiple Cropping; ASA Special Publication: Wisconsin, WI, USA, 1976; pp. 1-10.

8. Helenius, J. Intercropping, Insect Populations and Pest Damage: Case Study and Conceptual Model. Dep. Agric. For. Zool. Rep. 1989, 14, 1-49.

9. Cook, S.M.; Khan, Z.R.; Pickett, J.A. The use of push-pull strategies in Integrated Pest Management. Annu. Rev. Entomol. 2007, 52, 375-400. [CrossRef]

10. Jenkinson, J.G. The Incidence and control of cauliflower mosaic in broccoli in South-West England. Ann. Appl. Biol. 1955, 43, 409-422. [CrossRef]

11. Simons, J.N. Effects of insecticides and physical barriers on field spread of pepper veinbanding mosaic virus. Phytopathology 1957, 47, 139-145.

12. Brown, J.K.; Frohlich, D.R.; Rosell, R.C. The sweetpotato or silverleaf whiteflies: Biotypes of Bemisia tabaci or a species complex? Annu. Rev. Entomol. 1995, 40, 511-534. [CrossRef]

13. Oliveira, M.R.V.; Henneberry, T.J.; Anderson, P. History, current status, and collaborative research projects for Bemisia tabaci. Crop Prot. 2001, 20, 709-723. [CrossRef]

14. Boykin, L.M.; Shatters, R.G.; Rosell, R.C.; McKenzie, C.L.; Bagnall, R.A.; De Barro, P.; Frohlich, D.R. Global relationships of Bemisia tabaci (Hemiptera: Aleyrodidae) revealed using Bayesian analysis of mitochondrial COI DNA sequences. Mol. Phylogenet. Evol. 2007, 44, 1306-1319. [CrossRef] [PubMed]

15. Yokomi, R.K.; Hoelmer, K.A.; Osborne, L.S. Relationships between the sweetpotato whitefly and the squash silverleaf disorder. Phytopathology 1990, 80, 895-900. [CrossRef]

16. Zhang, X.M.; Yang, N.W.; Wan, F.H. Population density of Bemisia tabaci (Gennadius) (Hemiptera: Aleyrodidae) on different plants in the field. Acta Ecol. Sin. 2014, 34, 4652-4661. (In Chinese) [CrossRef] 
17. Wan, F.H.; Yang, N.W. Invasion and management of agricultural alien insects in China. Annu. Rev. Entomol. 2016, 61, 77-98. [CrossRef] [PubMed]

18. Feng, L.X.; Yang, Y.H.; Xie, B.Y.; Yang, C.R. Likely epidemics of virus diseases in vegetable crops caused by outbreaks of Bemisia tabaci. China Veg. 2001, 2, 34-35. (In Chinese) [CrossRef]

19. Nauen, R.; Stumpf, N.; Elbert, A. Toxicological and mechanistic studies on neonicotinoid cross resistance in Q-type Bemisia tabaci (Hemiptera: Aleyrodidae). Pest Manag. Sci. 2002, 58, 868-875. [CrossRef] [PubMed]

20. Rauch, N.; Nauen, R. Identification of biochemical markers linked to neonicotinoid cross resistance in Bemisia tabaci (Hemiptera: Aleyrodidae). Arch. Insect Biochem. 2003, 54, 165-176. [CrossRef]

21. Morales, J.R.; Dardón, D.E.; Salguero, V.E. IPM Plot Validation and Transfer in Tomato. Manual of Management of Tomato Pests; Ministerio de Agricultura, Ganaderia y Alimentacion: Guatemala City, Guatemala, 1993; pp. 1991-1992. (In Spanish)

22. Sharma, S.R.; Varma, A. Effect of cultural practices on virus infection in cowpea. Z. Acker Pflanzenbau 1984, 153, 23-31.

23. Rataul, H.S.; Gill, C.K.; Brar, S. Use of barrier crop and some cultural measures in the management of yellow mosaic virus on soybean. J. Res. Punjab Agric. Univ. 1989, 26, 227-230.

24. Gold, C.S.; Altieri, M.A.; Bellotti, A.C. Direct and residual effects of short duration intercrops on the cassava whiteflies Aleurotrachelus socialis and Trialeurodes variabilis (Homoptera: Aleyrodidae) in Colombia. Agric. Ecosyst. Environ. 1990, 32, 57-67. [CrossRef]

25. Fargette, D.; Fauquet, C. A preliminary study on the influence of intercropping maize and cassava on the spread of African cassava mosaic virus by whiteflies. Asp. Appl. Biol. 1998, 17, 195-202.

26. Zhang, X.M.; Lövei, G.L.; Ferrante, M.; Yang, N.W.; Wan, F.H. The potential of trap and barrier cropping to decrease densities of the whitefly Bemisia tabaci MED on cotton in China. Pest Manag. Sci. 2020, 76, 366-374. [CrossRef] [PubMed]

27. Gerling, D.; Horowitz, A.R.; Baumgaertner, J. Autecology of Bemisia tabaci. Agric. Ecosyst. Environ. 1986, 17, 5-19. [CrossRef]

28. Breene, R.G.; Meagher, R.L., Jr.; Nordlund, D.A.; Wang, Y.-T. Biological control of Bemisia tabaci (Homoptera: Aleyrodidae) in a greenhouse using Chrysoperla rufilabris (Neuroptera: Chrysopidae). Biol. Control 1992, 2, 9-14. [CrossRef]

29. Goolsby, J.A.; Ciomperlik, M.A.; Legaspi, B.C., Jr.; Legaspi, J.C.; Wendel, L.E. Laboratory and field evaluation of exotic parasitoids of Bemisia tabaci (Gennadius) (Biotype "B") (Homoptera: Aleyrodidae) in the lower Rio Grande Valley of Texas. Biol. Control 1998, 12, 127-135. [CrossRef]

30. Zolnerowich, G.; Rose, M. Eretmocerus haldeman (Hymenoptera: Aphelinidae) imported and released in the United States for control of Bemisia tabaci complex (Homoptera: Aleyrodidae). Proc. Entomol. Soc. Wash. 1998, 100, 310-323. [CrossRef]

31. Moreno-Ripoll, R.; Gabarra, R.; Symondson, W.O.C.; King, R.A.; Agustí, N. Do the interactions among natural enemies compromise the biological control of the whitefly Bemisia tabaci? J. Pest Sci. 2014, 87, $133-141$. [CrossRef]

32. Gerling, D.; Alomar, Ò.; Arnò, J. Biological control of Bemisia tabaci using predators and parasitoids. Crop Prot. 2001, 20, 779-799. [CrossRef]

33. Stansly, P.A.; Calvo, J.; Urbaneja, A. Release rates for control of Bemisia tabaci (Homoptera: Aleyrodidae) biotype "Q" with Eretmocerus mundus (Hymenoptera: Aphelinidae) in greenhouse tomato and pepper. Biol. Control 2005, 35, 124-133. [CrossRef]

34. Yang, N.W.; Wan, F.H. Host suitability of different instars of Bemisia tabaci biotype B for the parasitoid Eretmocerus hayati. Biol. Control 2011, 59, 313-317. [CrossRef]

35. De Barro, P.J.; Coombs, M.T. Post-release evaluation of Eretmocerus hayati Zolnerowich and Rose in Australia. Bull. Entomol. Res. 2009, 99, 193-206. [CrossRef] [PubMed]

36. Sivasubramaniam, V.; Subramaniam, S. Area-wide releases and evaluation of the parasitoid Eretmocerus hayati (Hymenoptera: Aphelinidae) for silverleaf whitefly control. In XXIX International Congress on Horticulture, International Symposia on Innovative Plant Protection in Horticulture, Biosecurity, Quarantine Pests, and Market Access; Hale, C., Hunter, D., Roberts, W., Ikin, R., McMaugh, S., Eds.; Acta Horticulturae: Brisbane, Australia, 2015; Volume 1105, pp. 81-88. 
37. Zhang, X.M.; Xu, H.Y.; Yang, N.W.; Wan, F.H. Field cage evaluation of the biocontrol effect of two aphelinid parasitoids on Bemisia tabaci Mediterranean (Hemiptera: Aleyrodidae). J. Plant Protect. 2018, 45, 1281-1288. (In Chinese) [CrossRef]

38. Collier, T.R.; Hunter, M.S. Lethal interference competition in the whitefly parasitoids Eretmocerus eremicus and Encarsia sophia. Oecologia 2001, 129, 147-154. [CrossRef] [PubMed]

39. Naranjo, S.E. Retrospective analysis of a classical biological control programme. J. Appl. Ecol. 2018, 55, 2439-2450. [CrossRef]

40. Heinz, K.M.; Nelson, J.M. Interspecific interactions among natural enemies of Bemisia in an inundative biological control program. Biol. Control 1996, 6, 384-393. [CrossRef]

41. Bográn, C.E.; Heinz, K.M.; Ciomperlik, M.A. Interspecific competition among insect parasitoids: Field experiments with whiteflies as hosts in cotton. Ecology 2002, 83, 653-668. [CrossRef]

42. Zhang, X.M.; Yang, N.W.; Wan, F.H.; Lövei, G.L. Density and seasonal dynamics of Bemisia tabaci (Gennadius) Mediterranean on common crops and weeds around cotton fields in northern China. J. Integr. Agric. 2014, 13, 2211-2220. [CrossRef]

43. Xu, H.Y.; Yang, N.W.; Wan, F.H. Female reproductive system and ovary development of two parasitoids of tobacco whitefly. Sci. Technol. Rev. 2015, 33, 79-83. (In Chinese) [CrossRef]

44. Jin, L.L.; Xu, M.; Wang, Z.S. Intercropping mode affecting yield and quality of cotton and peanut. Chin. Agric. Sci. Bull. 2018, 34, 51-55. (In Chinese)

45. R Core Team. A Language and Environment for Statistical Computing; Version 3.3.3; R Foundation for Statistical Computing: Vienna, Austria, 2019.

46. Brooks, M.E.; Kristensen, K.; van Benthem, K.J.; Magnusson, A.; Berg, C.W.; Nielsen, A.; Skaug, H.J.; Machler, M.; Bolker, B.M. glmmTMB balances speed and flexibility among packages for zero-inflated generalized linear mixed modeling. $R$ J. 2017, 9, 378-400. [CrossRef]

47. Lenth, R.V. Least-Squares Means: The R Package lsmeans. J. Stat. Softw. 2016, 69, 1-33. [CrossRef]

48. Fazekas, J.; Kádár, F.; Sárospataki, M.; Lövei, G.L. Seasonal activity, age structure and egg production of the ground beetle Anisodactylus signatus (Coleoptera: Carabidae) in Hungary. Eur. J. Entomol. 1997, 94, 473-484.

49. Zuur, A.F.; Ieno, E.N.; Elphick, C.S. A protocol for data exploration to avoid common statistical problems. Meth. Ecol. Evol. 2010, 1, 3-14. [CrossRef]

50. Zuur, A.F.; Hilbe, J.M.; Ieno, E.N. A Beginner's Guide to GLM and GLMM with R: A Frequentist and Bayesian Perspective for Ecologists; Highland Statistics Limited: Newburgh, UK, 2013.

51. Gingerich, A.J.; Philipp, D.P.; Suski, C.D. Effects of nutritional status on metabolic rate, exercise and recovery in a freshwater fish. J. Comp. Physiol. B 2010, 180, 371-384. [CrossRef] [PubMed]

52. Akaike, H. Information theory and an extension of the maximum likelihood principle. In Selected Papers of Hirotugu Akaike; Parzen, E., Tanabe, K., Kitagawa, G., Eds.; Springer Series in Statistics; Springer: New York, NY, USA, 1998; pp. 199-213.

53. Lavandero, B.; Wratten, S.; Shishehbor, P.; Worner, S. Enhancing the effectiveness of the parasitoid Diadegma semiclausum (Helen): Movement after use of nectar in the field. Biol. Control 2005, 34, 152-158. [CrossRef]

54. Irvin, N.A.; Scarratt, S.L.; Wratten, S.D.; Frampton, C.M.; Chapman, R.B.; Tylianakis, J.M. The effects of floral understoreys on parasitism of leafrollers (Lepidoptera: Tortricidae) on apples in New Zealand. Agric. For. Entomol. 2006, 8, 25-34. [CrossRef]

55. Gontijo, L.M.; Saldanha, A.V.; Souza, D.R.; Viana, R.S.; Bordin, B.C.; Antonio, A.C. Intercropping hampers the nocturnal biological control of aphids. Ann. Appl. Biol. 2018, 172, 148-159. [CrossRef]

56. Razze, J.M.; Liburd, O.E.; Webb, S.E. Intercropping buckwheat with squash to reduce insect pests and disease incidence and increase yield. Agroecol. Sustain. Food Syst. 2016, 40, 863-891. [CrossRef]

57. Hummel, J.D.; Dosdall, L.M.; Clayton, G.W.; Harker, K.N.; O’Donovan, J.T. Responses of the parasitoids of Delia radicum (Diptera: Anthomyiidae) to the vegetational diversity of intercrops. Biol. Control 2010, 55, 151-158. [CrossRef]

58. Kristensen, N.P.; Barro, P.J.D.; Schellhorn, N.A. The initial dispersal and spread of an intentional invader at three spatial scales. PLoS ONE 2013, 8, e62407. [CrossRef]

59. Castle, S.J. Concentration and management of Bemisia tabaci in cantaloupe as a trap crop for cotton. Crop Prot. 2006, 25, 574-584. [CrossRef] 
60. Mansion-Vaquié, A.; Ferrante, M.; Cook, S.M.; Pell, J.K.; Lövei, G.L. Manipulating field margins to increase predation intensity in fields of winter wheat (Triticum aestivum). J. Appl. Entomol. 2017, 141, 600-611. [CrossRef]

61. Landis, D.A.; Wratten, S.D.; Gurr, G.M. Habitat management to conserve natural enemies of arthropod pests in agriculture. Annu. Rev. Entomol. 2000, 45, 175-201. [CrossRef] [PubMed]

62. Hogg, B.N.; Bugg, R.L.; Daane, K.M. Attractiveness of common insectary and harvestable floral resources to beneficial insects. Biol. Control 2011, 56, 76-84. [CrossRef]

63. Balzan, M.V.; Wäckers, F.L. Flowers to selectively enhance the fitness of a host-feeding parasitoid: Adult feeding by Tuta absoluta and its parasitoid Necremnus Artynes. Biol. Control 2013, 67, 21-31. [CrossRef]

64. Benton, T.G.; Vickery, J.A.; Wilson, J.D. Farmland biodiversity: Is habitat heterogeneity the key? Trends Ecol. Evol. 2003, 18, 182-188. [CrossRef]

(C) 2020 by the authors. Licensee MDPI, Basel, Switzerland. This article is an open access article distributed under the terms and conditions of the Creative Commons Attribution (CC BY) license (http://creativecommons.org/licenses/by/4.0/). 